\title{
Meeting Death in Childhood
}

\author{
Tereza Antošovská \\ (Masaryk University, Brno)
}

\begin{abstract}
In ancient societies the mortality rate was at a far higher level than as we know it today. Especially childhood was a very dangerous phase of life and children were faced with death much more often - as potential victims or as witnesses of death in their family or community. Death was a rather common occurrence, and not some distant abstract concept. The Romans considered childhood a tender age requiring forming and protection. Can there be found any forms of "protection from death" - ritual, physical or psychological? And more importantly - can we (using an interdisciplinary approach) learn more about these children as witnesses of death in Roman society and about the children's experience with death and their agency when facing it?
\end{abstract}

\section{Keywords}

children; family; antiquity; Rome; mortality; death; sickness; agency 
In ancient societies the mortality rate was at a far higher level than today in the developed countries of Europe, with an average life expectancy "somewhere from the low 20 s to somewhere in the 30 s depending on the local disease environment". ${ }^{1}$ Especially childhood was a very dangerous phase of life and children faced death much more often - as potential victims or as witnesses of deaths in their family or community. Death was rather common, not some distant abstract concept as it may seem today.

I would like to initially focus on the "basic" demographic background of ancient society as it represents an important frame of the social reality necessary to keep in mind if we want to discuss problems with death as noted in the lives of children. Of course, there are the general inaccuracies with the results of modern demography for ancient Roman society (as statistical analysis of evidence has its gaps and limitation since it consists mainly of epigraphic and papyrological sources, ${ }^{2}$ combined with a comparison of data with other ${ }^{3}$ historical societies and periods richer for the survived data, has its gaps and limitation). ${ }^{4}$ Nevertheless, this does not reduce its importance for further studies of various matters concerning family life. Though we should be careful not to get too bogged down in demographical determinism, there is certainly a close relationship and a mutual influence between demographical regime and socio-cultural behaviour. This can be manifested (among other things) in the adaptation of emotional responses and dealing with death.

Though there are disputes among scholars addressing these demographical issues (e.g. Parkin, revising the traditional Coale-Denemy life-tablets, warns against an overevaluation of child mortality rates, while Atkinson on the contrary cautions against their underestimation), ${ }^{5}$ the pattern of very high child mortality as a cross-cultural phenomenon in premodern societies is unquestionable. ${ }^{6}$ For Roman society, the estimations of an infant ${ }^{7}$ child mortality rate range roughly between 200 to 300 deaths per 1000 births. Then only about $50 \%$ of children born were expected to live to adulthood. ${ }^{8}$ Various infectious and congenital diseases are supposed to be the most probable killers. Their impact was strengthened by the general sanitary condition, availability and quality of healthcare, poverty ${ }^{9}$ and undernutrition. Various diseases are followed by violence or

1 Scheidel (2007: p. 8).

2 Recently in the fields of demographical studies, paleo-archaeology and archaeology are exploited to the extent of their possibilities and limits - e.g. children are heavily underrepresented at burial sites, their bones can be missed, misinterpreted or not preserved at all since they are more fragile etc.; see e.g. Rawson (2003: pp. 341-342); Morris (1992: pp. 13-15, 72-81).

3 At least theoretically and probably similar when it comes to patterns of demographical regimes.

4 Due to the time limit this discussion needs to be omitted here. See for demography: e.g. Woods (1993; 2007); Parkin (2013); Volk \& Atkinson (2008; 2013); Scheidel (2007; 2009 a-c; 2010); Hopkins (1983: p. 225); Rawson (2003: pp. 104, 342-361); Nutton (2013: pp. 21-22).

5 Parkin (2013: pp. 48-50); Volk \& Atkinson (2013: pp. 183-184).

6 See e.g. the study by Volk \& Atkinson (2013: p. 186) that includes a table comparing various cultures and historical epochs.

7 That is of children before reaching their first birthday.

8 See the note 2 .

9 Though where it comes to a child's death, even the aristocratic families - with the best sources and pos- 
accidents as the cause of death. ${ }^{10}$ Though the Roman world lacked exact data from their everyday life experience, Romans were certainly very well aware of the dangers and of the high probability that as parents they will bury some of their children. ${ }^{11}$

Even though in ancient literary sources children are very marginal living beings, in everyday reality this was not the case. Children were of essential importance for the family from various perspectives - emotional (though we hardly have any means to measure and qualify that), ${ }^{12}$ biological, social, economic, even cult and religious. They represented (besides the "enjoyment" of the parents) a future for the family and its continuity (i.e. continuity of family lineage, name, property, status, family cult and rituals). They were an investment - offering potential hope for a better future of the family and for security in the old age of the parents as well as for the continual care of deceased ancestors in their afterlife. ${ }^{13}$ Death of a child crushed all of these hopes.

There is quite an amount of literature on the topic of child mortality from the parental point of view, discussing ways of dealing with loss, public displays of mourning or questioning the emotional bonds between parents and children. ${ }^{14}$ This is given largely by the character of our preserved historical sources. Nevertheless, a new trend ${ }^{15}$ has recently emerged in the field of childhood studies, due to the advances in, and the broadening of an interdisciplinary approach. Currently, it is needed to try and find methods as well as (and mainly) occurrences in sources which help scholars reach conclusions for a new set of questions where a child is not only a mere object, but also an active agent and participator of whatever is occurring in the family and society. On the theme of death,

sibilities of their time - did not avoid the high mortality pattern. This can be seen e.g. in cases of Cornelia, mother of the Grachii, Agrippina Maior and Germanicus, or Marcus Aurelius and Faustina. If there was some percent of difference, it is impossible for us to measure it.

10 See Volk \& Atkinson (2013) for the estimations; for healthcare and sanitary condition see closer e.g. Hope \& Marshall (2004); Laurence (2005); Morley (2005); Nutton (2013: pp. 19-36).

11 Cic. Cato 68; Sen. Dial. 6.9; 17.6-7; Plu. Moralia-Quest. Rom. 102.

12 However, we can trace some of the anxiety parents faced about the wellbeing of their children. Among the below mentioned attempts to protect the child, we can find these traces even in astrology. In this field we have stories about parents ordering horoscopes for their babies in concern about their life and future (Barton 1994: pp. 171-172; Laes 2011b: pp. 89-90). Astrology generally could be used to predict life and death in illness (Barton 1994: pp. 185-190).

13 A pattern we can see generally also in other societies throughout history, even in the modern Third world (Wyman 2009).

14 See e.g. Rawson (2003: pp. 336-363); Hopkins (1983: pp. 201-235); Hope (2009: pp. 121-150); McWilliams (2001: pp. 74-98); Huskinson (2005: pp. 91-104); Laes (2011a: pp. 315-330); Martin-Kilcher (2000).

15 Laes \& Vuolanto (2017); The main problem in this recent approach lies in the sources which rarely allow any glimpse that could help us as they reflect mostly the adult point of view. The reports about child's death or in a few cases, old (and thus possibly altered by time and adult perspective) memories from childhood hardly enable any broad generalization but might show us possible specific situations. There might be a potential of using interdisciplinary methods for a historian in attempts of applying the results and theories of anthropology (especially psychological) or developmental or evolutional psychology. However, even this application (if applied cautiously and based on a proper understanding of the comparative method and the familiarity of a historian with the complementary studies) at best leaves us with more or less theoretical prospective scenarios of the past and occasionally some sondes into particular cases. This can be attributed to the mostly theoretical character of these fields with the combination of socio-culture influences and specifics that are unique - opposing and accompanying cross-cultural and timeless similarities. 
this includes questions about children's agency when facing death, whether it would be their own or that of a relative (or the others in the society as such), or at the very least, a frame for this agency. ${ }^{16}$

Most ancient literary authors who refer to children in some regard perceived them as fragile, irrational, "incomplete" human beings. Childhood was generally seen as a tender, vulnerable and dependent age in which a "future adult citizen" should be formed and protected to reach his/her full potential and become a proper citizen. ${ }^{17}$ But what possibilities did the Romans have to protect their children from death? What was the child's role in this? In what ways could they help themselves? How could they act in assisting the adults (parents and healers) in their efforts?

We can trace the attempts of parents (or/and relatives) in keeping their children from harm on a magical and religious level by the usage of rituals and amulets ${ }^{18}$ for the protection from some "evil spirits", or illnesses that would cause death. Gods could have been invoked and given offerings. ${ }^{19}$ With the spread of Christianity and its stress on personal intimate faith, prayers to God by parents and children themselves (when old enough to be capable of such performance) also became important, ${ }^{20}$ as in later antiquity and in Christianity the concept of health condition was probably largely believed - except by those who would still hold to Hippocratic tradition - to be affected by God/demons/ devil. A cure was thus connected to the personal religiosity and morals, strengthening the idea of illness and death as a punishment. ${ }^{21}$ All these would of course also be used by the adults to protect themselves from any evils, as well. For children specifically, birth and subsequent purification and integration into a family and society by dies lustricus, or later by baptism, ${ }^{22}$ was accompanied by rituals and invocation of the supernatural. These

16 E.g. see the inspiring study by C. Horn in Laes \& Vuolanto (2017: pp. 300-317).

17 Protection of children can be seen even in Roman law - e.g. in institutions of tutella impuberum (and cura minorum for the young adults) as well as in the laws of inheritances in which the material interest (thus wellbeing) of the children is guarded. We could also mention the laws of emperors of late antiquity protecting the children's life and freedom against the violence also among the family by reducing the "absolute" patria potestas of the father (e.g. laws banning the practice of child exposure). See closer e.g. McGinn (2013); Vial-Dumas (2014); Skřejpek (2005); Saller (1986).

18 Plin. Nat. XXVIII.29; XXX.47; XXXVII.12.

19 Part of traditional Roman medicine, captured in work of Cato the Elder, were also magical formulas (Cato Agr. 141 - prayer to the Gods for health of the whole familia as well as for the yield). There are also many offerings found on archaeological sites connected with the care of one's health - as prayers or dedication and thanksgiving. Whether the child itself (if in age of such ability) would be asked to do the offerings to pagan gods, or if parent(s) would be responsible, would probably dependent on circumstances. Any answer here would lie only in the frame of speculation given lack of sources.

20 Aug. Conf. I.11.

21 Nutton (2013: pp. 31-32, 294-296); Holman (2009: pp. 145-148).

22 The dies lustricus and baptism itself represented specific rituals. Already the time of the holding of dies lustricus (at the 8th day after the birth in case of a girl, or the 9th day if a boy is concerned) reflected the threat of death during the very fragile first week of life. Awareness of this is expressed explicitly as one of the reasons to held this naming ceremony after the child had managed to survive its first week by Plutarch, Quest. Rom. 102. The main effect of this ritual was that the child was formally integrated into the family and recognized by the society as part of a particular family. The child thus gained a social protection and protection of the Lares as family thus assumed the responsibility for upbringing. This was very 
traditions (among other) reflect the attempt of giving the newborn - whose only way to "help itself" in its fragile condition is to cry loudly to get the attention of the adult ${ }^{23}$ - maximal chances through the desired help of divinity. However, all of these magical and religious "forms of protection" would most likely have had more of a psychological ${ }^{24}$ than actual effect on the physical condition of the child, by possibly partially appeasing the troubled minds of children (old enough to realize the seriousness of their condition) and parents likewise that "something was done at least".

Though in some cases, it is a question, of wouldn't more harm than good be done to the child, ${ }^{25}$ with the other parental solution of how to face a life-threatening condition (whether due to illness or injury) of their offspring. This was calling for medical assistance (if and where possible). ${ }^{26}$ In the rare case when a sick or dying child is even

important act especially in context of the right of pater familias to expose unfitted or unwanted child after the birth, which could easily result in death of the child if not found and taken by a stranger. For analysis of birth rituals see Dasen (2009; 2011); Hännien (2005); Laes (2011b: pp. 64-67).

The baptism here is more complicated in this sense as in times of early Christianity, the doctrine was just evolving and there were different opinions on child baptism and meaning of baptism as such. Baptism in the sense of integrating a baptised person into a Christian community would have a potential to offer a more of social protection and help within the community. In the context of a child's death, the idea of at least saving the child's soul by washing off the sins (including the primary sin that stains even the souls of the "not so innocent" infants; an idea which spread in popularity and influence especially since st. Augustine) in face of peril present itself for consideration. On baptism see e. g Ivanovska (2009); Bakke (2005: pp. 223-245); Horn \& Martens (2009: pp. 268-291); Wiedemann (1989: pp. 104-105, 190-195).

23 The theory of evolutional psychology has it that a child's crying can be understood as child's evolutionary adaptation for the purpose of securing its own survival. Quoted are e.g. studies done among the Masai, bringing up the conclusion that child who cries more and is more fussing manages to get greater attention of the parents and thus greater chances of surviving in dire conditions such as famine (Volk \& Atkinson). The famous ancient healer Soranus considered a child who was after the birth uncapable of "proper" loud crying as signalling that there is something wrong, that the child is sick or weak and he advised against the upbringing of such children (Sor. II.6.).

24 Though in the light of modern findings, we should not underestimate the importance of the psychological condition and state of mind of the person and its potential influence on physical condition, as they seem to have of great importance and interconnection (and can be the "causes" of some "miracles").

25 Given, despite all advances, some wrongs of the ancient medicine, existence of charlatans, possible unavailability of a well-trained physician for the family of the sick or injured child. Sidonius Apollinaris reflects this in a joke in a letter (Sidon. Epist. II.12.) in which he informs his son-in-law about the condition of his sick daughter where he is mocking the abilities of the healers qui parum docti et satis seduli languidos multos officiosissime occidunt, (for with their scanty knowledge and immense zeal they most dutifully kill many sick folks). Lack of trust in the abilities of healers, except one family friend, not improving condition of the girl (or more probably young woman as age is not specified) by up to now methods, leads the family to journey to the countryside (considered generally a healthier environment than the city, especially for respiratory problems, which seems to be the case) and entrusting their hopes to Christ.

26 Through a proper physician (who can be present especially in the cases of children of well-to-do families) or through following some traditional folkloric receipts for healing by local healers. The question of ancient medicine and possible prevention for children is better to leave for medical historians to discuss. Nevertheless, it could be noted briefly that the ancient treatment emphasized a proper regimen, appropriate food and exercise, and/or change of climate condition (such as moving from the city to countryside, as is the case in Sid. II.12), depending on the illness. These methods could be used as treatment as well as prevention (with the problem of cause and consequences). Frankly, hardly anything else could be done as prevention given the state of scientific knowledge. Upper-class families with their own physicians at their disposal could have done more for their children in terms of "prevention" as theoretically they could have 
mentioned in ancient literature, physicians are present (vaguely) at the scene, giving advice. ${ }^{27}$

In medical literature (Galen, Celsus) the child as a patient is obliged to be obediently "active" during the cure, ${ }^{28}$ especially as the treatment is not unusually based on (or accompanied with) proper diet and exercise, which the parents ${ }^{29}$ (with check-ups by the physician) are to monitor. Et ex toto non sic pueri ut viri curari debent. ${ }^{30}$ Ancient medicine (Greek Hippocratic tradition as well as the traditional Roman folk medicine where the pater familias was responsible for the health and the cure of his household) ${ }^{31}$ was well aware of this fact. ${ }^{32}$ Even though pointing out this "simple fact" could also indicate that some potential charlatans or poorly qualified "physicians" might have ignored this. Additionally, there was an awareness of child-specific diseases and even seasonal differences in regards to dangers to the child's health and life. ${ }^{33}$ Though to what extent "ancient paediatrics" actually existed is better left for medical historians to discuss.

In the few extant descriptions of children fighting serious diseases, facing death or even the potential of dying, ${ }^{34}$ anxious members of the household are often delineated at the scene. The focus lies mainly on parents, but sometimes - albeit vaguely - also siblings, educators as well as household slaves are indicated. However, for us the more important question in this survey is how is the child captured in these situations in literature?

had better continuous medical monitoring and "proper" advices at hand. For the common folk, as almost always for antiquity, there is hard to guess their possibilities for preventive care, or whether it was something the person of antiquity would actually considered as important instead of calling upon the healers in times of troubles. Also, the question of how often people would decide to obey or disobey advice is also impossible to answer.

27 Quint. Inst. VI. praef. 11; Plin. Epist. V.16.4; Sid. Epist. II.12; Paul. Pell. Euch. 125. These are of course references by and about elite Roman families. For the role of the physicians in these situations see e.g. Bradley (2005: pp. 80-83); Hope (2009: pp. 49-54).

28 Though I did not come across the reference that would mention it explicitly.

29 With the possible important similar role of the child's caretakers (such as the nurse; or guardians and other relatives in case of the orphan) as well.

30 Cels. III.7 (Indeed in general children ought not to be treated like adults).

31 Represented typically in the person and work of Cato the Elder.

32 E.g. in treatment by vine, children should have it mixed to mild concoction with water (Cels. I.3), when accompanied by diet and fasting, children should not be exposed to "harsh" long fasting (Cels. I.3; III.4), Galen mentions some type of food, that is generally good for children, but not for men (Gal. De alimentorum facultatibus $2.32=6.554-659 \mathrm{~K}$ ) and is strictly against the usage of venesection on children younger than 14 years (Gal. De Curandi Ratione per Venae Sectionem $6=\mathrm{K} 267 ; 9=\mathrm{K} 277$ ), though in this case, Celsus on the contrary claims, that this procedure can be performed even on children after thorough consideration of their condition, especially their strength (Cels. II.10).

33 Medical theories in antiquity considered the natural conditions - season, weather and place - to be of great importance to one's health condition along with lifestyle (considering both - physical and spiritual exercising and quality of food). Generally late summer months are considered to be the most dangerous for children, but this differs and is also dependent on the geographic location. See the studies of Harper (2015); Shaw (1996); Scheidel (2013: pp. 45-49) for closer inspection of seasonal mortality; on ancient medicine see e.g. Nutton (2000; 2013); Mattern (2008).

34 E.g. Plin. Epist. V.16 (daughter of his friend), Quint. Inst. VI. praef. (both his sons), Plu. Moralia-Cons. ad uxorem and Sidon. Epist. II.12 (their daughters), Paul. Pell. Euch. 113-140 and Aug. Conf. I.11 (memories of their own situation). 
Unfortunately, we are left with very few examples (and on top of that, from varied time periods) to look at. ${ }^{35}$

Two cases that do exist are the rare recorded memories (unfortunately very brief and not immersing into much detail) of an author's experience with a severe disease in childhood: Paulinus of Pella ${ }^{36}$ and Augustine ${ }^{37}$ both describe their concerned parents who had tried to do everything in their powers to ensure the survival of the child (in Paulinus's case both of the parents, Augustine - given his poor relationship with his pagan father - mentions only the devotion of his mother). Both memories being (distant) ${ }^{38}$ reminiscences of fear and anxiety during the struggle with the illness, that have further implications to their subsequent life, which they view critically in their adulthood through the optics of their later found Christian devotion. ${ }^{39}$

In the case of Paulinus of Pella,${ }^{40}$ the remembrance of an illness he faced at an age of a little less than 15 years old, is for him important in the context of the studies he used to love and as an important turning point in his childhood and youth. What is important to note in the narrative is the compliance of the advice of his healers. Paulinus mentions his anxiety over his own health condition and the love his parents, especially through the actions of his father, who, in obeying the physician, actively supervised the recommended activities that were to strengthen the child's weakened body. Paulinus was thus taken - by the sickness and by the subsequent treatment - from his studies to the world of hunting and amusement, thus gaining long term disgust at his further studies even after he regained his health. This led him in his youth to further pursue these "youthful desires". ${ }^{41}$

Augustine's memory of sickness when he was a young boy, ${ }^{42}$ reflects another "possible approach" as it focuses on his spirituality and his faith (and faith of his mother). His short, but intense stomach pain made him fear for his own life, as he thought he was going to die. In his faith in God, gained from his mother (which even his father could not undermine) he turned to God, asking for baptism. His anxious mother tried to achieve this rite, but due to Augustine's sudden recovery, this baptism was then postponed. ${ }^{43}$ Here, what matters is the child's faith, a plea for absolution in the face of his possible

35 To my present knowledge at least and omitting the hagiographical genre of later antiquity due to its particularity.

36 Quartan fever; Paul. Pell. Euch. 113-140.

37 Unspecified; Aug. Conf. I.11.

38 For a closer analysis of their memories and on the problematics of methodology to these memories see Southon (2012: pp. 240-241); Freud (2016: pp. 45-53).

39 The question and theme of conversion and penance in this critical view of oneself being of importance here in the context of the personal Christian spirituality as well as faith and conformity with theology.

40 Paul. Pell. Euch. 113-140.

41 Unfortunately, Paulinus does not mention much about his feelings during the illness, except for his lack of willingness to learn.

42 Exact age is not specified, as it was obviously not important for Augustine.

43 Aug. Conf. I.11. 
death and the plan of God in Augustine's further life. ${ }^{44}$ No healer or treatment are mentioned, though this does not categorically exclude the possibility that some treatment other than the prayers and the preparation for "the worst" was actually applied (whether some folk/home remedy or a consultation with a local physician that might have occurred) as these "secular aspects" were not important in the message Augustine wanted to convey in his book.

One letter (Sidon. Epist. II.12.) captures an anxious father who writes about the lack of improvement in the health condition of his daughter, who was fighting with a serious cough and he speaks briefly about her behaviour. He mentions his daughter's anxiety, the anticipation (hers as well as his) and delight from planning a stay in the countryside, which was to ameliorate her condition, as other methods used so far had failed. ${ }^{45}$

When it comes to children's agency in a dangerous situation, sometimes a child was to take their own immediate action to save its own life (especially if no adult at the moment was present at the time of severe injury). One case in Celsus refers to a boy who saved himself from a fatal snake bite by drinking vinegar. No adult is present here to help the child, and the child's self-help in "treating himself" in this crucial moment seems to be more a mere chance success in Celsus' description, rather than some application of any form of "first self-help" knowledge. ${ }^{46}$

These children who survived were the lucky ones. However, sometimes ${ }^{47}$ practically nothing could be done to save the child, not only because medicine was not capable of

44 In which his sudden recovery before receiving the baptism and its subsequent postponing "had saved" Augustine from even heavier sinning in his youth as his youthful sins before his "finding of the right way in Catholic church" would be far more severe if he had been already baptized.

See also n. 27.

46 Cels. V.27: Haec adversus omnes ictus communia sunt. Usus tamen ipse docuit eum, quem aspis percussit, acetum potius bibere debere. Quod demonstrasse dicitur casus cuiusdam pueri, qui cum ab hac ictus esset et partim ob ipsum volnus partim ob inmodicus aestus siti premeretur ac locis siccis alium umorem non reperiret, acetum, quod forte secum habebat, ebibit et liberatus est, credo, quoniam id, quamvis refrigerandi vim habet, tamen habet etiam dissupandi; quo fit, ut terra respersa eo spumet. Eadem ergo vi verisimile est spissescentem quoque intus umorem hominis ab eo discuti et sic dari sanitatem.

("Such are the general remedies against bites of any kind. Experience has taught, however, that anyone bitten by an asp should in particular drink vinegar. The case of a certain boy is said to demonstrate this, for having been thus bitten, partly on account of the bite, and partly owing to excessively hot weather, he was tormented by thirst, and being in a dry place found no other fluid, so he drank the vinegar he chanced to have with him, and was saved. I believe this happened because although vinegar is a refrigerant, it has also the faculty of dissipating. Hence it is that earth sprinkled with it froths. Therefore, it is likely that by the same faculty humour which is condensing inside a patient is dissipated by it, and so health is restored.") (Translation from used edition).

Unfortunately, we do not know anything about the child - his age, origin, etc. Given the common presence of snakes in the Mediterranean, children were likely to be taught by the experience of elders what to do and how to deal with snakes if it was not possible to avoid them. However, we have no information about transmitting any common knowledge about immediate self-help due to more or less severe injuries (in general, not only by snake's bite) to children, but their encounter with them would most probably be at much higher frequency than in the over-protective modern western world. Thus we could presume also the higher ability to handle some types of injuries to some limited manner - again, if the child would be old enough, as there are great differences between a 5 or 10 year old child.

Though this would be "many times" in reality most probably, though the evidence preserved is scarce. 
providing a proper treatment, and prayers to whichever god were not answered, ${ }^{48}$ but also because of the percentage ${ }^{49}$ of violent deaths and fatal accidents, where death was unexpected, immediate, and without any chance for "preparation time" (on both sides). Such as in the case of Ausonius's grandson, who died from a head injury when a tile from a roof fell on his head. ${ }^{50}$ However, let us refer to the situation of a child's struggle with disease, this time fatal. These are described in to the Preface to the sixth book of Quintilian's Institutio Oratoria, where he mourns his two deceased sons, and in a letter of Pliny the Younger about the death of the daughter of his Fundanus (i.e. Ep. V. 16).

In general, in the surviving literature, we can see the stress on a "good death," 51 a theme that reflects the common fears of death. ${ }^{52}$ This topos is accompanied with the popular motif of consolatory literature called puer senex, ${ }^{53}$ which ascribes to the child behaviour not considered typical in young age and reflects the lost potential the child might have had in a future. It is this lost promise that is mainly mourned by the parents. ${ }^{54}$ The child deals with his/her fatal disease at home, surrounded by loving members of the family and faces their inevitable fate with strength, bravery, calmness and

48 Children and miraculous healings in hagiographies omitted due to the specification of the genre.

49 Though most of the child's death would be caused by diseases that take some time, or congenital problems; see Volk \& Atkinson (2013: p. 187); Rawson (2003: pp. 342-343); for children and accidents see articles of Graumann (2017: pp. 267-279) and Laes (2004).

50 Auson. Parentalia (IV. 11); who is to be blamed - at least according to the poem dedicated to the deceased boy - is the fate itself, not the workers (no charges of unintentional killing are mentioned), nor the child (for walking where he should not, or for not being careful enough), nor the paidagoges (for not watching over). Though of course this is a personal example, one sonde to the mind and memory of one grandfather giving last honour to his once (we do not know the time frame of the event and the poem being written) lost grandson, memory written with poetic license. Whether this would be an actual reaction of the family, or a consideration after some time of mourning and conciliation is impossible to know, and even if, it would still be impossible to generalise.

51 For the theme of "good death" see Noy (2011: pp. 1-7); Hope (2009: pp. 50-57).

52 "Like adults, dying children are concerned that they will be comfortable, safe, and not alone" (Corr \& Balk 2010: p. 160). This belongs to general anxieties, along with the need and wish of comfort at home, presence of the significant persons, "safety" that help to keep the last bits of dignity to the dying person. Death in reconciliation, dignity, and proper performance of the rites connected with death and burial, so a soul can rest in peace, are parts of the idea of "good death" (see the note above).

53 To see the closer analysis of puer senex as literary motif see Curtius (1998: pp. 113-120). Literary motif can reflect the social expectations, and in this context also a possible wish of the adults for the child. As a topos, there is a certain suppression of the child's individuality to some extent by the "common frame" even though, on the other hand, by the motif itself there is an attempt to credit the child some of this individuality by ascribing to the child some of the great qualities that are mourned (early maturity, high level of intelligence and wisdom beyond the child's age, courage etc.). Modern psychological research suggests individuality and dependence on child's age when considering the awareness of death and agency of seriously ill children, given their personal experience with both these phenomena (Corr \& Balk 2010: pp. 153-160). There can be largely any doubt that for ancient children the awareness of their death and their perception of death would be shaped by their experience of living in a world with higher mortality levels and certain "domesticity of death" - compared to modern "expulsion" of real (in contrast to "movie") death in the western world. However (given both the pattern of individuality as well as lack of proper sources), answering the question "exactly how different or similar would be facing one's own mortality?" can lie only in the realm of speculation.

54 E.g.: Quint. Inst. VI.Praef., Plin. Epist. V.16., Plu. Moralia-Cons. ad uxorem; also Stat. Silv. II.1, II.6, V.5 (in these last cases about deliciae and vernae, not freeborn children). 
serenity. In both cases, the child is active, and seems to be reconciled and is himself/ herself trying to be the support for the rest of the family. ${ }^{55}$ Besides being "mere" literary motifs or conventions, these themes reflect the social reality and expectation, anxieties and wishes, which might also serve as consolation, as well as a coping mechanism for death in keeping with the "desired positive memories" about the deceased. ${ }^{56}$

Let the sources speak for themselves:

Illa maiora, constantia, gravitas, contra dolores etiam ac metus robur. Nam quo ille animo, qua medicorum admiratione mensium octo valetudinem tulit! ut me in supremis consolatus est! quam etiam deficiens iamque non noster ipsum illum alienatae mentis errorem circa scholas ac litteras habuit! . $^{57}$

55 Some psychological research based on observation of interaction of the dying child with his/her family suggest the very real possibility of quite premature behaviour that would correspond with higher age. Some children when facing death (their own as well as death of the sibling or other family member) can in this situation react more maturely than expected. They can actively search by their behaviour and responses how to alleviate the situation for the other members of the family. Children can come to the state of composure and conciliation with their condition quite sooner than the parent and bear the definitiveness "more calmly" at the end. Again, this is largely individual, however, mortal diagnosis essentially changes the mentality of the persons involved - the child and his/her family members. This is dependent on child's age as the ability to comprehend one's own mortality and its finality as well as the comprehension of the dying process (when the notion of long-term illness becomes the notion of "final" illness and death) must be present in the child to act like previously mentioned. That is, to act almost similarly to ancient topos of an "old child" facing death. According to developmental psychology, children generally tend to start understanding this from 9 years of age, even earlier, if they e.g. grow up in more violent context with closer encounters with death (such as in time of war). (Corr \& Balk 2010: pp. 25-27/9; Ulrichová 2010: pp. 108-110; 2014: pp. 78-82; Thorová 2015: pp. 489-492).

56 These coping strategies, preserved in literary sources, reflect the ideas of the Roman elite for which public appearance and self-representation were important aspects of life and duty. The real experience of death and bereavement could be more unrestrained. However, it is hard to penetrate in the lower social strata of the Roman world. Despite the demographic regime, "studies of other societies have shown that the frequency of child deaths and therefore the expectation of losing at least some children early does not make parents inure to such loss" (Rawson 2003: pp. 346-347). Lament over the lost potential of the offspring emerges as a reflection of lost hopes given into the child. The ideal good death and the "idealisation" of dying scene in the literature is part of this, as the situation of these memories may not have been so "calm" in reality of the present moment of very emotional situation. Tense calmness at the scene of dying, intense mourning of the dead after, question of showing some last respect/honour to the dying, keeping a good memory and forgetting the bad as a form of consolation and a way of dealing with the loss (good memories suggested as a way of consolation e.g. in Plu. Moralia-Cons. ad uxorem 8; Stat. Silv. II.1) and question of clarity of the memory of what happened and how the bereaved person wanted it to have happened to cope with it, and/or ability to stand up to social norms and ideals; these can underlie the context of the references in the literature, that should not be dismissed merely as some literary motif. As the literary motif might be based on the need of a respectable putting up with the death of the child. Excessive public "show off" mourning (as in case of Regulus, as referred by Plin. Epist. IV.2.) was considered inappropriate (at least in the world of self-representation of an aristocrat). On the other hand, the absolute lack of mourning - despite the traditional restriction on public mourning especially for infants, as advised by legendary Numa Pompilius (Plu. Num. 12); similar pattern is repeated in the opinions of the lawyer Paulus (Paul. Sent. I. 21.13) - was considered inhuman and insensate even by the stoic philosopher Seneca (Epist. 99.24) according to his letter in which he is rebuking his friend for his grief over the loss of an infant boy, known more to his nurse than his father and showing yet no potential that is to be mourned. For mourning the child see also e.g. Hope (2009: pp. 137-141); Laes (2011a); Larsson Lovén (2013); Hopkins (1983: pp. 217-226); Carroll (2012: pp. 48-51); Rawson (2003: pp. 337-348).

"He had finer qualities, courage and dignity, and the strength to resist both fear and pain. What fortitude 
(Quint. Inst. VI.Praef.11)

Qua illa temperantia, qua patientia, qua etiam constantia novissimam valetudinem tulit! Medicis obsequebatur, sororem, patrem adhortabatur, ipsamque se destitutam corporis viribus vigore animi sustinebat. Duravit hic illi usque ad extremum nec aut spatio valetudinis aut metu mortis infractus est, quo plures gravioresque nobis causas relinqueret et desiderii et doloris. ${ }^{58}$ (Plin. Epist. V.16)

In this brief survey I have made an attempt to provide a glimpse of situations in which a child would face his/her own mortality. Of course, that is only one perspective on the topic of children's meeting death. The other possibility is to concentrate on the bereaved child. Given the high mortality pattern and lower average life expectancy, many children would have faced the fate of losing one or both parents at quite an early age, ${ }^{59}$ and of course, they would have been the witnesses of deaths of other relatives in the family, or of their siblings and friends. Though unfortunately, sources for application of this point of view face the very similar problem of paucity and scattering as the theme discussed above.

Of course, we can never reach and fully comprehend how children in ancient Roman society would actually have thought, felt about, or even coped with their own death. This theme is difficult even for modern psychologists with far more data and immediate contact, not to mention, even with the existence of some common patterns. Moreover, it is also a theme too difficult to generalize, as it is highly unique and depending on a child's experience with death and life in society. ${ }^{60}$ The only thing we can frailly manage is to set up a frame of possibilities given by socio-cultural realities. Mourning has a clear cultural anchoring and coping with death will also be affected by the general attitudes of a society about death and the dead, despite, again, some general commonalities. Nevertheless, for shedding some light on the situation of Roman children - to the sad knowledge of the historians of childhood - we lack the data to get much closer.

he showed during an illness of eight months till all his physicians marvelled at him! How he consoled me during his last moments. How even in the wanderings of delirium did his thoughts recur to his lessons and his literary studies, even when his strength was sinking and he was no longer ours to claim!" (Translation from used edition).

58 "With what forbearance, patience, nay courage, did she endure her last illness! She complied with all the directions of her physicians; she encouraged her sister and her father; and when all the strength of body was exhausted, supported herself by the single vigour of her mind. That, indeed continued even to her last moments, unbroken by the pain of a long illness, or the terrors of approaching death; and it is the reflection which makes the loss of her so much the more to be lamented." (Translation from used edition).

59 Scheidel (2009a: p. 37).

60 Corr \& Balk (2010: pp. 22-39, 139-142, 147-166, 216-217, 451-452); Ulrichová (2014: pp. 77-82, 92-96); Thorová (2015: pp. 475-504). 


\section{Bibliography}

\section{Primary sources}

Anderson, W. B. (Ed.). (1963). Sidonius: Poems and Letters (2 vols.). Cambridge, Mass.: Harvard University Press.

Armistead Falconer, W. (Ed.). (1923). Marcus Tullius Cicero: De Senectute. De Amicitia. De Divinatione. Cambridge: University Press.

Bahník, V. et. al. (Eds.). (2006). Plútarchos: Životopisy slavných Řeků a Římanů (Vol. I). Praha: Svoboda.

Bahník, V., \& Vysoký, K. (Transl.). (1987). Plútarchos. O lásce a pŕátelství. Praha: Svoboda.

Basore, J. W. (Ed.). (1932). Lucius Annaeus Seneca: Moral Essays (Vol. II). London - New York: Heinemann.

Baviera, J. (Ed.). (1909). Pauli Sententiae. In J. Baviera (Ed.), Fontes Iuris Romani Anteiustiniani (Vol. II; pp. 259-347). Florentiae: Apud G. Barbèra.

Brain, P. (Ed.). (2009). Galen on bloodletting: a study of the origins, development and validity of his opinions, with a translation of the three works. Cambridge: University Press.

Butler, H. E. (Ed.). (1963). The Institutio Oratoria of Quintilian: in four volumes. London: William Heinemann.

Evelyn-White, H. G. (Ed.). (1919). Ausonius (Vol. 1). Cambridge, Mass. - London: Harvard University Press.

Evelyn-White, H. G. (Ed.). (1921). Ausonius with the Eucharisticus of Paulinus Pellaeus (Vol. 2). Cambridge, Mass. - London: Harvard University Press.

Grant, M. (Ed.). (2000). Galen: On Food and Diet. London: Routledge.

Gummere, R. M. (Ed.). (1917-1925). Seneca: Ad Lucilium Epistulae Morales (Vol. 1-3). Cambridge, Mass.: Harvard University Press.

Harrison Boyd, A., \& Hooper, W. D. (Ed.). (1934). Cato: On Agriculture. Cambridge, Mass.: Harvard University Press.

Helmbold, W. C. (Ed.). (1939). Plútarchos: Moralia (Vol. 6). Harvard: Loeb Classical Library edition. Mayhoff, K. F. T. (Ed.). (1906). Pliny the Elder: Naturalis Historia. Lipsiae: Teubner.

Melmoth, W., \& Hutchinson, W. M. L. (Ed.). (1963). Pliny: Letters (2. vols.). London: William Heinemann.

Page, T. E., \& Rouse, W. H. D. (Eds.). (1912). Aurelius Augustinus: Confessiones (Vol. 1-2). London: William Heinemann.

Powell, O. W. (Ed.). (2003). Galen: On the Properties of Foodstuffs. Cambridge: University Press.

Shackleton Bailey, D. R. (Ed.). (2003). Statius: Silvae. Cambridge, Mass.: Harvard University Press. Spencer, W. G. (Ed.). (1971). Celsus: De Medicina. Cambridge, Mass.: Harvard University Press.

Temkin, O. (Ed.). (1956). Soranus: Gynaecology. Baltimore: Johns Hopkins University Press.

\section{Secondary sources}

Bakke, O. M. (2005). When Children Became People: The Birth of Childhood in Early Christianity. Minneapolis: Fortress Press. 
Barton, T. (1994). Ancient astrology. London - New York: Routledge.

Bradley, K. R. (2005). The Roman Child in Sickness and Health. In M. George (Ed.), The Roman Family in the Empire. Rome, Italy and Beyond (pp. 67-92). Oxford: University Press.

Carroll, M. (2012). "No Part in Earthly Things.” The Death, Burial and Commemoration of Newborn Children in Roman Italy. In M. Harlow, \& L. Larsson Lovén, Families in the Roman and Late Antique World (pp. 41-63). London - New York: Continuum.

Corr, Ch., \& Balk, D. E. (2010). Children's Encounters with Death, Bereavement, and Coping. New York: Springer.

Curtius E. R. (1998). Evropská literatura a latinský středověk. Praha: Triáda.

Dasen, V. (2009). Roman Birth Rites of Passage Revisited. Journal of Roman Archaeology, 22, 199-214.

Dasen, V. (2011). Childbirth and Infancy in Greek and Roman Antiquity. In B. Rawson (Ed.), A Companion to Families in Greek and Roman Worlds (pp. 291-314). Malden, Mass.: Wiley-Blackwell.

Freud, S. (2016). Psychopatologie všedního života: O zapomínáni, přeřeknutí, přehmátnutí, pověre a omylu. Praha: Portál.

Graumann, L. A. (2017). Children's accidents in the Roman Empire. In Ch. Laes, \& V. Vuolanto (Eds.), Children and everyday life in the Roman and late antique world (pp. 267-286). New York: Routledge.

Hännien, M. L. (2005). From Womb to Family. Rituals and Social Conventions Connected to Roman Birth. In K. Mustakallio et al. (Eds.), Hoping for Continuity: Childhood, Education and Death in Antiquity and the Middle Ages (pp. 49-60). Rome: Inst. Romanum Finlandiae.

Harper, K. (2015). A time to die: Preliminary notes on seasonal mortality in late antique Rome. In Ch. Laes, K. Mustakallio, \& V. Vuolanto, Children and family in late antiquity: life, death and interaction (pp. 15-34). Leuven: Peeters.

Holman, S. R. (2009). Sick children and healing saints: Medical treatment of the child in Christian antiquity. In C. B. Horn, \& R. Phenix (Eds.), Children in Late Ancient Christianity (Studien und Texte zu Antike und Christentum, 58; pp. 143-170). Tübingen: Mohr Siebeck.

Hope, V. (2009). Roman death: the dying and the dead in Ancient Rome. London: Continuum.

Hope, V., \& Marshall, E. (Eds.). (2004). Death and Disease in the Ancient City. London - New York: Routledge.

Hopkins, K. (1983). Death and Renewal. Cambridge: University Press.

Horn, C. B., \& Martens, J. W. (2009). 'Let the Little Children Come to Me': Childhood and Children in Early Christianity. Washington DC: The Catholic University of America Press.

Huskinson, J. (2005). Disappearing children? Children in Roman funerary art of the first to the fourth century AD. In K. Mustakallio et al. (Eds.), Hoping for Continuity: Childhood, Education and Death in Antiquity and the Middle Ages (pp. 91-103). Rome: Inst. Romanum Finlandiae.

Ivanovska I. (2009). Baptized Infants and Pagan Rituals: Cyprian versus Augustine. In C. B. Horn, \& R. Phenix (Eds.), Children in Late Ancient Christianity (Studien und Texte zu Antike und Christentum, 58; pp. 45-74). Tübingen: Mohr Siebeck.

Laes, Ch. (2004). Children and Accidents in Roman Antiquity. Ancient Society, 34, 153-170.

Laes, Ch. (2011a). Grieving for Lost Children, Pagan and Christian. In B. Rawson (Ed.), A Companion to Families in the Greek and Roman Worlds (pp. 315-330). Malden, Mass.: Wiley-Blackwell. Laes, Ch. (2011b). Children in Roman Empire: outsiders whithin. Cambridge: University Press. 
Laes, Ch., \& Vuolanto, V. (Eds.). (2017). Children and everyday life in the Roman and late antique world. New York: Routledge.

Larsson Lovén, L. (2013). Children and childhood in Roman commemorative art. In J. E. Grubbs, T. Parkin, \& R. Bell (Eds.), The Oxford Handbook of Childhood and Education in the Classical World (pp. 302-321). Oxford: University Press.

Laurence, R. (2005). Health and the Life Course at Herculaneum and Pompeii. In H. King (Ed.), Health in Antiquity (pp. 83-96). London: Routledge.

Martin-Kilcher, S. (2000). Mors immatura in the Roman world - a mirror of society tradition. In J. Pearce, M. Millet, \& M. Struck (Eds.), Burial, society and context in the Roman world (pp. 63-77). Oxford: Oxbow Books.

Mattern, S. P. (2008). Galen and the rhetoric of healing. Baltimore: John Hopkins University Press.

McGinn, T. A. J. (2013). Roman children and the law. In J. E. Grubbs, T. Parkin, \& R. Bell (Eds.), The Oxford Handbook of Childhood and Education in the Classical World (pp. 341-360). Oxford: University Press.

McWilliams, J. (2001). Children among the dead: the influence of urban life on the commemoration of children on tombstone inscriptions. In S. Dixon (Ed.), Childhood, Class and Kin in the Roman World (pp. 74-98). London - New York: Routledge.

Morley, N. (2005). The Salubriousness of Roman City. In H. King (Ed.), Health in Antiquity (pp. 192-204). London: Routledge.

Morris, I. (1992). Death-ritual and social structure in classical antiquity. Cambridge: University Press.

Noy, D. (2011). 'Goodbye Livia': Dying in the Roman Home. In J. Huskinson, \& V. Hope (Eds.), Memory and Mourning: Studies on Roman Death (pp. 1-20). Havertown: Oxbow Books.

Nutton, V. (2000). Medicine. In A. K. Bowman, P. D. A. Garnsey, \& D. Rathbone (Eds.), The Cambridge Ancient History, XI: The High Empire, A.D. 70-192 (pp. 943-968). Cambridge: University Press.

Nutton, V. (2013). Ancient Medicine (2nd ed.). New York: Routledge.

Parkin, T. (2013). The Demography of Infancy and Early Childhood in the Ancient World. In J. E. Grubbs (Ed.), The Oxford Handbook of Childhood and Education in the Classical World (pp. 40-61). Oxford: University Press.

Rawson, B. (2003). Children and childhood in Roman Italy. Oxford: Oxford University Press.

Saller, R. P. (1986). Patria potestas and the stereotype of the Roman family. Continuity and Change, $1,7-22$.

Scheidel, W. (2007). Epigraphy and demography: birth, marriage, family, and death. Princeton/Stanford Working Papers in Classics [retrieved 02.05.2018 from https://www.princeton.edu/ pswpc/ pdfs/scheidel/060701.pdf].

Scheidel, W. (2009a). The demographic background. In S. R. Hübner, \& D. M. Ratzan (Eds.), Growing up fatherless in antiquity (pp. 31-40). Cambridge: University Press.

Scheidel, W. (2009b). Population and Demography. In A. Erskine (Ed.), A Companion to Ancient History (pp. 134-145). Malden, Mass.: Wiley-Blackwell.

Scheidel, W. (2009c). Demography and sociology. In G. Boys-Stones, B. Graziosi, \& P. Vasunia (Eds.), The Oxford handbook of Hellenic studies (pp. 665-677). Oxford: Oxford University Press.

Scheidel, W. (2013). Disease and death. In P. Erdkamp (Ed.), The Cambridge companion to ancient Rome (pp. 45-59). Cambridge: University Press. 
Shaw, B. D. (1996). Seasons of death: aspects of mortality in imperial Rome. Journal of Roman Studies, 86, 100-138.

Skřejpek, M. (2005). Moc bez hranic? (Právo otce římské rodiny nad životem a smrtí). Právni rozhledy, 15, 549-557.

Southon, E. (2012). Fatherhood in Late Antique Gaul. In M. Harlow, \& L. Larsson Lovén (Eds.), Families in the Roman and Late Antique World (pp. 238-253). London - New York: Continuum.

Thorová, K. (2015). Vývojová psychologie: proměny lidské psychiky od početi po smrt. Praha: Portál.

Ulrichová, M. (2010). Smrt - krize a kairos smyslu: Logoterapeutická perspektiva. In J. Bednaříková et al., Krize a kairos: společenské výzuy (pp. 105-120). Červený Kostelec: Pavel Mervart.

Ulrichová, M. (2014). Hledáni smyslu ve smrti a umírání. Ostrava: Moravapress.

Vial-Dumas, M. (2014). Parents, Children, and Law: Patria Potestas and Emancipation in the Christian Mediterranean during Late Antiquity and the Early Middle Ages. Journal of Family History, 39(4), 307-329.

Volk, A. A., \& Atkinson, J. A. (2008). Is child death the crucible of human evolution? Journal of Social, Evolutionary, and Cultural Psychology, 2(4), 247-260.

Volk, A. A., \& Atkinson, J. A. (2013). Infant and child death in the human environment of evolutionary adaptation. Evolution and Human Behaviour, 34, 182-192.

Wiedemann, T. (1989). Adults and Children in the Roman Empire. New York: Routledge.

Woods, R. (2007). Ancient and Early modern mortality: experience and understanding. Economic History Review, 60(2), 373-399.

Woods, R. (1993). On the historical relationship between infant and adult mortality. Population Studies, 47, 195-219.

Wyman, R. (2009). Global Problems of Population Growth (Yale University: Open Yale Courses). License: Creative Commons BY-NC-SA [retrieved 30.8.2017 from https:/ /oyc.yale.edu/molecularcellular-and-developmental-biology/mcdb-150].

Mgr. Tereza Antošovská / 440233@mail.muni.cz

Department of Classical Studies

Masaryk University, Faculty of Arts

Arna Nováka 1, 60200 Brno, Czech Republic 
